\title{
Innovation and Development in Information Technology in India: Specific to Software Industry
}

\author{
Deepak Kumar Solanki ${ }^{1}$ \\ Kunal Sinha ${ }^{2}$ \\ ${ }^{1,2}$ Centre for Studies in Science, Technology and Innovation Policy, \\ Central University of Gujarat, Gandhinagar, Gujarat.
}

\begin{abstract}
Information technology (IT) plays an important role in development of business, boosting economic growth and employment by energising higher education sector. Software sector is a major component of IT industry. Development of indigenous software products is necessary for nation's economy through development in software industry. Under 'Digital India' and 'Make In India' programmes major institutions are involved in policies and initiative programmes, $R \& D$ and innovation for growth of software industry. The paper attempts to highlight the crucial contribution of key stakeholders such as universities, technical research institute and private-public software firms, STPI and industrial association for development of software products and services. The Indian Government has taken many initiatives for promotion and adoption of Free \& Open Source Software for increasing foreign exchanges, developing indigenous products and achieving vendor's independence. The paper raise question about unavailability of indigenous software products as compared to Microsoft and other foreign vendor's products in Indian market. Various institutions are still working on creation of indigenous software and in upcoming time novel products and technologies will be provided by India to domestic and global IT market.
\end{abstract}

Keywords: Research and development, information technology, software, innovation, cloud computing.

\section{INTRODUCTION}

Information Technology is an important emerging sector for the Indian economic growth and employment (Vijayasri, 2013). The last decade was remarkable for the Indian IT industry in the form of Information Technology/ Information Technology Enabled Services (IT/ITES) industry that has transformed India's image on the global platform. India's cost competitiveness in providing IT services is approximately 3-4 times cheaper than the United States. IT-ITES industry has reached US\$ 100 billion export revenues in the year 2012 (Bhattacharjee and Chakrabarti, 2015) and almost generated US\$ 117 billion for the year 2016-17 (Deity, 2017).

IT-ITES industry has emerged as one of the most dynamic sector in India's economic development and is responsible for the global recognition of India as a 'soft' power. India is being recognised as the outsourcing destination of the world and known for its reliable and cost-effective delivery of cloud computing services. IT industry has set up over 600 delivery centres across

Journal of Technology Management for Growing Economies Vol. 8, No. 2 October, 2017 pp. 129-144

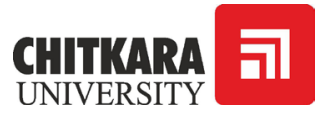

(C)2017 by Chitkara University. All Rights Reserved. 
Solanki, D. K. Sinha, K. the world and providing services with presence in over 200 cities across 78 countries (Deity.gov.in, 2015).The industry has grown at compound annual growth rate (CAGR) of over 21\% during the year 1998-2014. The Indian IT industry's contribution to GDP increased from $1.2 \%$ in FY 1998 to an estimated 8.1\% in FY 2014 (NASSCOM, 2014).

In the year 2000, IT industry added another changing dimension in form of BPO/ITES business. These BPO/ITES included call-centres, KPO, BPO, insurance claim processing, financial and accounting processing, non-banking services including insurance, pension, asset, management and market related services.

Table 1: Year wise IT - ITES Industry's Export Trends in India (in USD billion)

\begin{tabular}{|l|l|l|l|l|l|l|l|l|l|l|}
\hline \multicolumn{1}{|c|}{ Year } & $\begin{array}{l}\mathbf{2 0 0 7 -} \\
\mathbf{0 8}\end{array}$ & $\begin{array}{l}\mathbf{2 0 0 8 -} \\
\mathbf{0 9}\end{array}$ & $\begin{array}{l}\mathbf{2 0 0 9 -} \\
\mathbf{1 0}\end{array}$ & $\begin{array}{l}\mathbf{2 0 1 0 -} \\
\mathbf{1 1}\end{array}$ & $\mathbf{2 0 1 1 - 1 2}$ & $\begin{array}{l}\mathbf{2 0 1 2 -} \\
\mathbf{1 3}\end{array}$ & $\begin{array}{l}\mathbf{2 0 1 3 -} \\
\mathbf{1 4}\end{array}$ & $\begin{array}{l}\mathbf{2 0 1 4} \\
\mathbf{1 5}\end{array}$ & $\begin{array}{l}\mathbf{2 0 1 5 -} \\
\mathbf{1 6}\end{array}$ & $\begin{array}{l}\mathbf{2 0 1 6} \\
\mathbf{1 7}\end{array}$ \\
\hline IT Services & 22.2 & 25.8 & 27.3 & 33.5 & 39.9 & 45.4 & 51.9 & 55.3 & 61.00 & 66.00 \\
\hline ITES-BPO & 9.9 & 11.7 & 12.4 & 14.2 & 15.9 & 17.9 & 19.9 & 22.5 & 24.2 & 26.0 \\
\hline $\begin{array}{l}\text { Software } \\
\text { Products, } \\
\text { Engi- } \\
\text { neering } \\
\text { Services }\end{array}$ & 8.3 & 9.6 & 10 & 11.4 & 13 & 12.8 & 14.2 & & & \\
\hline $\begin{array}{l}\text { Total } \\
\text { IT-ITES }\end{array}$ & $\mathbf{4 0 . 4}$ & $\mathbf{4 7 . 1}$ & $\mathbf{4 9 . 7}$ & $\mathbf{5 9}$ & $\mathbf{6 8 . 8}$ & $\mathbf{7 6 . 1}$ & $\mathbf{8 6}$ & $\mathbf{9 7 . 8}$ & $\mathbf{1 0 7 . 8}$ & $\mathbf{1 1 7 . 0}$ \\
\hline
\end{tabular}

Source: Own compiled on the basis of data given by Sharma, 2014 and Deity, 2017.

Note: IT-ITES- Information Technology - Information Technology Enabled Services

The preceding table indicate the broader picture of Indian IT-ITES Industry's export performance. IT services exports (excludes BPO, engineering and software products) is expected to be fastest growing segment in the year 201617 in terms of generating exports of USD 66.0 billion and ITES/BPO exports is USD 26.0 billion. The Software products and engineering services have generated export of US\$25.0 billion in the year 2016-17. Above table shows the high demand of ITES/BPO services that affected production and export of indigenous software in domestic and international software market. Our local software firm's key interest is to attract foreign firms for ITES or BPO service and lesser in indigenous software product development.

\section{Purpose and Objectives}

The present study focuses on struggling growth of local software production in India in the current scenario. It also describes the government's role in

Journal of Technology Management for Growing Economies, Volume 8, Number 2, October 2017 
technological research, policy level, development and diffusion for improved indigenous software products. The Indian software industry mainly depends on outsourced work from other countries. India largely has Microsoft dependent environment and foreign vendor's software products in terms of operating system and its usage in computers, tablets and smart phones. Study emphasises the role of public-private institutions, technical institutes, STPI and industrial association and understands the interaction between various actors in development and diffusion of software products. The paper aims to highlight the following research objectives.

\section{Objectives of the Research:}

1. To analyse the role of various actors of National Innovation System specific to the software innovation in India.

2. To present the current status of foreign and Indian software products in Indian IT market.

3. To examine the role of government at policy level for Indian software firms.

\section{Methodology}

The present study will be qualitative, quantitative and exploratory in its detail. The descriptive and analytical aspects of events and their interaction with various determining linkages at various levels will be explored. Study is based on secondary data collected through various reports of software companies such as TCS, INFOSYS, C-DAC, BISAG and NASSCOM, STPI reports along with government reports. The secondary information has been collected from text books, magazines, journals, newspapers and internet.

\section{Theoretical Framework}

Fagerberg (2005), states that, Invention is the first occurrence of an idea for a new product or process, while innovation is the first attempt to carry it out in practice. As a theoretical framework the present study uses national innovation system because it permits to study activities, actors, norms, rules, relationships and other factors which influence innovation. Freeman (1987), describes NIS as the network of institutions in public and private sectors whose activities and interactions initiate, import, modify and diffusenew technologies. Lundvall(1992) explains, NIS as system of innovation constituted by elements and relationships which interact in creation, diffusion and use of new knowledge for economical purpose. Further, it is narrowly defined by Nelson and Rosenberg (1993) as a set of institutions whose interactions determine the innovation performance such as R\&D institutions, technological institutions and universities.

Journal of Technology Management for Growing Economies, Volume 8, Number 2, October 2017
Innovation and Development in Information 
Solanki, D. K. PRESENCE OF SOFTWARE INDUSTRY IN INDIA

Sinha, K.

Software industry is seen as a key opportunity for developing countries like India for "socio-economic development" (Mohammed, 2010). By the 1990s, Indian software industry achieved superb advancement in the growth of employment, sales and export. The creation of NASSCOM in 1988 and later establishment of STP in 1990 shows serious approach of policy makers for the software industry. The establishment of STP scheme in various cities such as Bangalore, Delhi, Hyderabad, Bombay and Chennai facilitated private software firms to export software and thus entry into USA software market was ensured (Nicholson and Sahay, 2008). The software and services industry generated almost US\$ 108 billion in export revenue for the year 2015-16 (STPI, 2016).

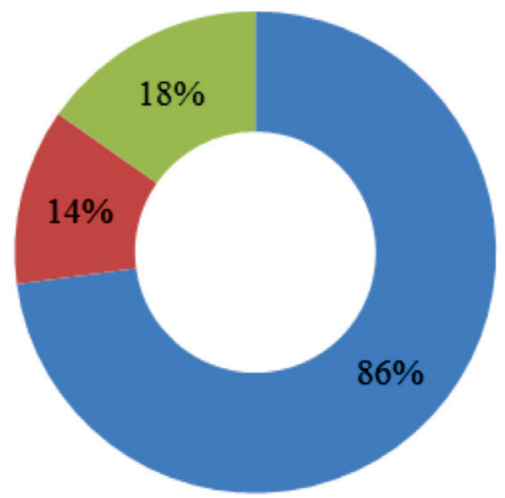

Indian Software Comanies(TCS, Infosys, Wipro etc)

- Multinational Software Companies (HP, Accenture, IBM, Microsoft,Cap Gemini etc)

Global Inhouse Center(EMC,Honeywell etc)

Figure 1: Dominant of national and multinational IT-Software companies in India Source: Adapted from Kulkarni, 2015

The above figure 1 shows the presence of Indian and international IT software companies in India. There are dominant Indian software companies having share of $86 \%$, multinational companies' share of $14 \%$ and global in-house centre having share of $18 \%$ in the Indian IT software industry. The government IT policies, schemes, establishment of NASSCOM, STP and SEZ parks are key contributors in the growth of Indian software companies (Kulkarni, 2015). The industry involves various emerging technologies such as Cloud Computing and Big Data. The emergence of cloud computing innovation added to technological breakthrough through improved products and services in Indian IT market (Buyya et.al, 2013). The use of this new technology by industries, government, non-government organizations and consumers are rapidly increasingly in the developing world. The cloud services market in India was $\$ 315$ million in the year 2012 which is expected to grow to US\$2 billion in 2018 (Kshetri et.al, 2017).

Journal of Technology Management for Growing Economies, Volume 8, Number 2, October 2017 


\section{Software}

Software is a collection of commands and instructions for data processing and performing several tasks (Grohn, 1999). Software is designed and developed by computer engineers specifically aimed to manage day to day data transactions of enterprises, banks, educational institutes, hospitals and many more. Software developed with the help of programming languages can be defined as a complex and recombinant system of commands and instructions for data processing, besides being an intangible good which can be used only in discrete units (Engelhardt, 2008). The basic programs or commands or instructions is written in a specific software programming language (for example, $\mathrm{C}, \mathrm{C}++$, Python, Java, etc.) to tell the computer what to do in order to perform certain tasks. The list of commands or source programs (source code) is translated into machine level language so that computer can easily understand and execute the program.

\section{Availabilities of Foreign and Indian Software Products}

The current scenario of availabilities of indigenous OS (Operating System) like BOSS (Bharat Operating System Solution) as compared to other foreign OS like Windows which are used in computer, laptop and smart phone are very less. We are highly dependent on foreign software products. The Government of India making policies and initiative programs for adoption of OSS (Open Source Software) in the country. National Resource Centre for Free \& Open Source Software (NRCFOSS) and BOSS are key initiatives in area of Free \& Open Source Software which started in 2005. Both are funded by the Department of Electronics and Information Technology coordinated by C-DAC (Deity.gov, 2015). Table 2 and another table 3 given below shows availabilities of OS in India and several other foreign countries which are using computer, laptop and smart phone. There are several different versions of Windows OS launched by Microsoft. India also introduced first Linux based OS BOSS 1.0 (Tarang) by C-DAC company in 2006.

Table 2: Availabilities of Foreign and Indian Software Products for Computer and Laptop

\begin{tabular}{|c|c|c|c|c|c|c|c|c|}
\hline & \multicolumn{4}{|c|}{$\begin{array}{c}\text { Foreign Software Products (operating } \\
\text { system) }\end{array}$} & \multicolumn{4}{|c|}{ Indian Software Products (operating system) } \\
\hline $\begin{array}{l}\text { Sr. } \\
\text { No. }\end{array}$ & $\begin{array}{l}\text { Product } \\
\text { Name }\end{array}$ & Company & $\begin{array}{l}\text { Descrip- } \\
\text { tion }\end{array}$ & $\begin{array}{l}\text { Price } \\
\text { (Rs.) }\end{array}$ & $\begin{array}{l}\text { Product } \\
\text { Name }\end{array}$ & Company & $\begin{array}{l}\text { Descrip- } \\
\text { tion }\end{array}$ & $\begin{array}{l}\text { Price } \\
\text { (Rs.) }\end{array}$ \\
\hline 1 & $\begin{array}{l}\text { DOS } 2.0 \\
\text { released in } \\
1983\end{array}$ & $\begin{array}{l}\text { Microsoft } \\
\text { Corpora- } \\
\text { tion, USA }\end{array}$ & $\begin{array}{l}\text { Operat- } \\
\text { ing sys- } \\
\text { tem used } \\
\text { in PC \& } \\
\text { Laptops }\end{array}$ & NA & $\begin{array}{l}\text { BOSS1.0 } \\
\text { (Ta- } \\
\text { rang)-re- } \\
\text { leased in } \\
\text { January } \\
2006\end{array}$ & $\begin{array}{l}\text { C-DAC } \\
\text { Pune }\end{array}$ & $\begin{array}{l}\text { Op- } \\
\text { erating sys- } \\
\text { tem used } \\
\text { in PC \& } \\
\text { Laptops }\end{array}$ & Free \\
\hline
\end{tabular}

Journal of Technology Management for Growing Economies, Volume 8, Number 2, October 2017
Innovation and Development in Information 
Solanki, D. K. Sinha, K.

\begin{tabular}{|l|l|l|l|l|l|l|l|l|}
\hline $\begin{array}{l}\text { Sr. } \\
\text { No. }\end{array}$ & $\begin{array}{l}\text { Product } \\
\text { Name }\end{array}$ & Company & $\begin{array}{l}\text { Descrip- } \\
\text { tion }\end{array}$ & $\begin{array}{l}\text { Price } \\
\text { (Rs.) }\end{array}$ & $\begin{array}{l}\text { Product } \\
\text { Name }\end{array}$ & Company & $\begin{array}{l}\text { Descrip- } \\
\text { tion }\end{array}$ & $\begin{array}{l}\text { Price } \\
\text { (Rs.) }\end{array}$ \\
\hline 2 & $\begin{array}{l}\text { Windows } \\
\text { reased in }\end{array}$ & $\begin{array}{l}\text { Microsoft } \\
\text { Corpora- } \\
\text { tion, USA }\end{array}$ & $\begin{array}{l}\text { Operat- } \\
\text { ing sys- } \\
\text { tem used } \\
\text { in PC \& } \\
\text { Laptops }\end{array}$ & NA & $\begin{array}{l}\text { BOSS 2.0 } \\
\text { (Anant) } \\
\text {-released in } \\
\text { Sept, 2007 }\end{array}$ & $\begin{array}{l}\text { C-DAC } \\
\text { Pune }\end{array}$ & $\begin{array}{l}\text { Op- } \\
\text { erating sys- } \\
\text { tem used } \\
\text { in PC \& } \\
\text { Laptops }\end{array}$ & Free \\
\hline 3 & $\begin{array}{l}\text { Win- } \\
\text { dows-XP } \\
\text { released in } \\
2001\end{array}$ & $\begin{array}{l}\text { Microsoft } \\
\text { Corpora- } \\
\text { tion, USA }\end{array}$ & $\begin{array}{l}\text { Operat- } \\
\text { ing sys- } \\
\text { tem used } \\
\text { in PC \& } \\
\text { Laptops }\end{array}$ & NA & $\begin{array}{l}\text { BOSS 3.0 } \\
\text { (Tejas) - } \\
\text { released in } \\
\text { Sept, 2008 }\end{array}$ & $\begin{array}{l}\text { C-DAC } \\
\text { - Pune }\end{array}$ & $\begin{array}{l}\text { Op- } \\
\text { erating sys- } \\
\text { tem used } \\
\text { in PC \& } \\
\text { Laptops }\end{array}$ & Free \\
\hline 4 & $\begin{array}{l}\text { Windows } \\
\text { Vista } \\
\text { released in } \\
2006\end{array}$ & $\begin{array}{l}\text { Microsoft } \\
\text { Corpora- } \\
\text { tion, USA }\end{array}$ & $\begin{array}{l}\text { Operat- } \\
\text { ing sys- } \\
\text { tem used } \\
\text { in PC \& } \\
\text { Laptops }\end{array}$ & NA & $\begin{array}{l}\text { BOSS 4.0 } \\
\text { (savir) - } \\
\text { released in } \\
\text { April, 2011 }\end{array}$ & $\begin{array}{l}\text { C-DAC } \\
\text { - Pune }\end{array}$ & $\begin{array}{l}\text { Op- } \\
\text { erating sys- } \\
\text { tem used } \\
\text { in PC \& } \\
\text { Laptops }\end{array}$ & Free \\
\hline 5 & $\begin{array}{l}\text { Windows 7 } \\
\text { released in } \\
2009\end{array}$ & $\begin{array}{l}\text { Microsoft } \\
\text { Corpora- } \\
\text { tion, USA }\end{array}$ & $\begin{array}{l}\text { Operat- } \\
\text { ing sys- } \\
\text { tem used } \\
\text { in PC \& } \\
\text { Laptops }\end{array}$ & 7,100 & $\begin{array}{l}\text { BOSS 5.0 } \\
\text { (anokha) } \\
\text { released in } \\
\text { Sept,2013 }\end{array}$ & $\begin{array}{l}\text { C-DAC } \\
\text { - Pune }\end{array}$ & $\begin{array}{l}\text { Op- } \\
\text { erating sys- } \\
\text { tem used } \\
\text { in PC \& } \\
\text { Laptops }\end{array}$ & Free \\
\hline 6 & $\begin{array}{l}\text { Windows } \\
\mathbf{1 0} \text { released } \\
\text { in 2014 }\end{array}$ & $\begin{array}{l}\text { Microsoft } \\
\text { Corpora- } \\
\text { tion, USA }\end{array}$ & $\begin{array}{l}\text { Operat- } \\
\text { ing sys- } \\
\text { tem used } \\
\text { in PC \& } \\
\text { Laptops }\end{array}$ & 7,999 & $\begin{array}{l}\text { BOSS 6.0 } \\
\text { anoop) } \\
\text { released in } \\
2014\end{array}$ & $\begin{array}{l}\text { C-DAC } \\
\text { - Pune }\end{array}$ & $\begin{array}{l}\text { Op- } \\
\text { erating sys- } \\
\text { tem used } \\
\text { in PC \& } \\
\text { Laptops }\end{array}$ & Free \\
\hline
\end{tabular}

Source: Author compiled it from annual reports of firms

Note: NA-Not Available

C-DAC - Centre for Development of Advanced Computing, BOSS -Bharat Operating System Solution

Table 3: Availabilities of Foreign and Indian Software Products for Smartphone and Tablet

\begin{tabular}{|l|l|l|l|l|l|l|l|l|}
\hline \multicolumn{2}{|c|}{ Foreign Software Products (operating system for Smart- } \\
phone and tablet)
\end{tabular}

Journal of Technology Management for Growing Economies, Volume 8, Number 2, October 2017 


\begin{tabular}{|l|l|l|l|l|l|l|l|l|}
\hline $\begin{array}{l}\text { Sr. } \\
\text { No. }\end{array}$ & $\begin{array}{l}\text { Product } \\
\text { Name }\end{array}$ & Company & Description & $\begin{array}{l}\text { Prics } \\
\text { (Rs.) }\end{array}$ & $\begin{array}{l}\text { Product } \\
\text { Name }\end{array}$ & $\begin{array}{l}\text { Com- } \\
\text { pany }\end{array}$ & $\begin{array}{l}\text { Descrip- } \\
\text { tion }\end{array}$ & $\begin{array}{l}\text { Price } \\
\text { (Rs.) }\end{array}$ \\
\hline 2 & $\begin{array}{l}\text { GINGER- } \\
\text { BREAD } \\
\text { Android } \\
2.3) \\
\text { released in } \\
\text { Nov- 2010 }\end{array}$ & $\begin{array}{l}\text { Google -Cali- } \\
\text { fornia, (USA) }\end{array}$ & $\begin{array}{l}\text { Operating } \\
\text { System used } \\
\text { in smart- } \\
\text { phone and } \\
\text { tablet }\end{array}$ & NA & NA & NA & NA & NA \\
\hline 3 & $\begin{array}{l}\text { Lollipop } \\
\text { Android } \\
5.0) \\
\text { released in } \\
\text { Oct-2014 }\end{array}$ & $\begin{array}{l}\text { Google -Cali- } \\
\text { fornia, (USA) }\end{array}$ & $\begin{array}{l}\text { Operating } \\
\text { System used } \\
\text { in smart- } \\
\text { phone and } \\
\text { tablet }\end{array}$ & NA & NA & NA & NA & NA \\
\hline 4 & $\begin{array}{l}\text { Marshmal- } \\
\text { low (An- } \\
\text { droid 6.X) } \\
\text { released in } \\
\text { March-2016 }\end{array}$ & $\begin{array}{l}\text { Google -Cali- } \\
\text { fornia, (USA) }\end{array}$ & $\begin{array}{l}\text { Operating } \\
\text { System used } \\
\text { in smart- } \\
\text { phone and } \\
\text { tablet }\end{array}$ & NA & NA & NA & NA & NA \\
\hline
\end{tabular}

Innovation and

Development in

Information

Source: http://androidadvices.com/androids-gingerbread-honeycomb-and-icecream/, accessed on April 10, 2016

Note: NA- Not Available

The preceding table 3 indicates the availabilities of foreign and Indian software products for Smartphone and tablets. The Google also introduced several different version of Android operating system such as Cupcake, Lollipop, and Marshmallow for tablets and smart phone. The whole market of operating system for Smartphone and tablets is acquired by the foreign companies, namely Google, Sony, Apple, and Microsoft. Android OS almost covers all the latest functionality of Smartphone and provides fast service to users. The developing country like India is still working on creation of operating system like Android. India has not produced any indigenous operating system for Smartphone and tablets till now. In future latest technologies will be provided by India to national and international software market.

\section{MAJOR ACTORS OF NIS FOR SOFTWARE DEVELOPMENT INDUSTRY IN INDIA}

The $21^{\text {st }}$ century witnessed software sector as the largest and fastest growing sector of Indian economy. The Indian government is promoting 'Digital India programme' as an umbrella programme to prepare India for knowledge based transformation into a digitally empowered society along with knowledge based economy. The present study deals with major actors and networks of institutions in NIS that led to transition of Indian software industry since the early 1970s. The GOI has invested considerable resources to build finest infrastructure for the development of domestic software capabilities. 
Solanki, D. K. Role of Higher and Technical Institutions

Sinha, K.

Higher and technical institutions of India are one of the biggest educational systems across the world being just after USA and China. Technical education is the most successful tool to create a knowledge-based society for the future world (MHRD, 2015).The growing technical, skilled and quality manpower created by several higher technical institutions is one of the major achievements in Indian education system. In the early 1960s, high demand and importance of higher technical education led to establishment of central, state engineering institutes and IITs. By the 1974, M.Tech and B.Tech got started at major IITs and other institutions. In the year 1982, two new courses started such as MCA and DCA. The new polytechnic diploma courses started in 1984. The DoE was set up by DOEACC society in the year 1990 to provide computer courses such as ' $O$ ', 'A', 'B', 'C' level courses. This DOEACC society had established 699 technical institutes by the 2000 across country (Kumar and Joseph, 2006). The total number of central and state funded institutions for technical and science education are 46 central universities, 310 state public universities, 130 deemed universities, 20 new IITs, 31 NITs, 4 IIITs and 6 IISERs in the year 2016 (MHRD, 2016).

Table 4: Region Wise Technical Institutes for Polytechnic, Engineering and MCA courses in India-2015

\begin{tabular}{|l|l|c|c|c|}
\hline $\begin{array}{l}\text { Sr } \\
\text { No }\end{array}$ & \multicolumn{1}{|c|}{ Region Wise } & $\begin{array}{l}\text { Polytechnic Insti- } \\
\text { tutes(Diploma/BE/ } \\
\text { ME) }\end{array}$ & $\begin{array}{l}\text { Engineering and } \\
\text { Technology Institutes } \\
\text { (B.Tech / M.Tech) }\end{array}$ & $\begin{array}{l}\text { MCA-Insti- } \\
\text { tutes }\end{array}$ \\
\hline 1 & $\begin{array}{l}\text { Central Region (Chhat- } \\
\text { tisgarh, Gujarat, Madhya } \\
\text { Pradesh) }\end{array}$ & 231 & 540 & 182 \\
\hline 2 & $\begin{array}{l}\text { Eastern Region } \\
\text { Arunachal Pradesh, } \\
\text { Assam, Jharkhand, Mani- } \\
\text { pur, Meghalaya, Orissa, } \\
\text { Tripura, West Bengal) }\end{array}$ & 222 & 422 & 104 \\
\hline 3 & $\begin{array}{l}\text { North-West Region } \\
\text { (Chandigarh, Delhi, } \\
\text { Haryana, Himachal } \\
\text { Pradesh, J\&K, Punjab, } \\
\text { Rajasthan, })\end{array}$ & 635 & 1029 & 226 \\
\hline 4 & $\begin{array}{l}\text { Northern Region (Bi- } \\
\text { har,UP, Uttarakhand) }\end{array}$ & 365 & & 674 \\
\hline 5 & $\begin{array}{l}\text { South-Central Re- } \\
\text { gion(Andhra Pradesh) }\end{array}$ & 297 & 500 & 144 \\
\hline 6 & $\begin{array}{l}\text { South-West Region(Kar- } \\
\text { nataka, Kerala) }\end{array}$ & 318 & 598 & 333 \\
\hline 7 & $\begin{array}{l}\text { Southern Region } \\
\text { (Puducherry, Tamil Nadu) }\end{array}$ & 462 & & \\
\hline
\end{tabular}

Journal of Technology Management for Growing Economies, Volume 8, Number 2, October 2017 


\begin{tabular}{|l|l|c|c|c|}
\hline $\begin{array}{l}\text { Sr. } \\
\text { No. }\end{array}$ & Region Wise & $\begin{array}{l}\text { Polytechnic Insti- } \\
\text { tutes(Diploma/BE/ } \\
\text { ME) }\end{array}$ & $\begin{array}{l}\text { Engineering and } \\
\text { Technology Institutes } \\
\text { (B.Tech / M.Tech) }\end{array}$ & $\begin{array}{l}\text { MCA-Insti- } \\
\text { tutes }\end{array}$ \\
\hline 8 & $\begin{array}{l}\text { Western Region } \\
\text { (Daman and Diu, Goa, } \\
\text { Maharashtra) }\end{array}$ & 609 & 750 & 148 \\
\hline & Grand Total & $\mathbf{3 1 3 9}$ & $\mathbf{5 1 9 4}$ & $\mathbf{1 8 1 1}$ \\
\hline
\end{tabular}

Innovation and

Development in

Information

Source: Author compilation based on AICTE, 2015

IITs, NITs, IIITs and Polytechnics/Engineering institutes run technical courses are well known for their excellence and supplier of quality manpower for the IT- Software companies. The above table 4 gives information about growth of region wise technical institutions such as polytechnic, engineering \& technology and MCA institutes. In the current year, region wise availability of total 3139 Polytechnic institutes, 5194 engineering \& technology institutes and 1811 MCA institutes. These technical institutions produce large pool of scientific and technical human resource for the Indian IT-Software firms. The largest pool of scientists, engineers and technicians has increased from 24,689 in the year 1956 to 609,079 in year 2003 (Chadha et.al, 2015). In the year 2016 it reached about 1,329,685 (AICTE, 2016).

\section{Role of Government at Policy Level}

The Government of India played a significant role in the growth of IT-ITeS sector in India (Parthsarathi, 2004). Software industries of India are major part of the IT-ITeS sector. The early initiatives of government contributed to the growth of software development activities like Bhabha Committee of 1963, Electronics Committee by Dr. Sarabhai in the year 1966 and National Conference on Electronics of 1970. DoE (Department of Electronics) was established in 1970 to create and implement policies of government for welfare of electronics sector including IT-Software industries. In the year $1999 \mathrm{DoE}$ was upgraded into a new ministry called Ministry of Information Technology (MIT). This ministry coordinated all the policies and initiative programmes for the development of software firms through improving software exports (Kumar, 2001).

Table 5: Government's Policies for Software Development in India

\begin{tabular}{|c|c|l|l|}
\hline Sr. No & Year & \multicolumn{1}{|c|}{ Policy } & \multicolumn{1}{c|}{ Description of Policy } \\
\hline 1 & 1972 & $\begin{array}{l}\text { Software Export } \\
\text { Scheme }\end{array}$ & $\begin{array}{l}\text { Government launched new 'Software Export Scheme' where there was provi- } \\
\text { sion for hardware import in exchange of software exports. The purpose of Indian } \\
\text { government behind formulating scheme was to earn foreign revenue. }\end{array}$ \\
\hline
\end{tabular}




\section{Solanki, D. K. Sinha, K.}

\begin{tabular}{|c|c|c|c|}
\hline $\begin{array}{l}\text { Sr. } \\
\text { No. }\end{array}$ & Year & Policy & Description of Policy \\
\hline 2 & 1976 & $\begin{array}{l}\text { Liberalisation of } \\
\text { policies related } \\
\text { to software } \\
\text { industry }\end{array}$ & $\begin{array}{l}\text { The government took initial measures to liberalise the policy for software export } \\
\text { by constituting EPZs and making provisions for easy and faster clearance of } \\
\text { software export applications. Import duties on hardware were also reduced from } \\
100 \% \text { to } 40 \% \text {. }\end{array}$ \\
\hline 3 & 1981 & $\begin{array}{l}\text { Software Export } \\
\text { Policy }\end{array}$ & $\begin{array}{l}\text { According to this policy, the duty on hardware was increased in order to raise } \\
\text { the demand of domestic computer system. Software development firms could } \\
\text { also import 'loaned' computer system. }\end{array}$ \\
\hline 4 & 1984 & $\begin{array}{l}\text { New Computer } \\
\text { Policy }\end{array}$ & $\begin{array}{l}\text { The procedures of import simplified, import of application software products } \\
\text { were allowed and import duty also decreased. Import duties on hardware } \\
\text { decreased from } 100 \% \text { to } 60 \% \text { for software programmers. This policy provided } \\
\text { many concessions such as firms getting loans from banks and duty exemptions. } \\
\text { Software products were exempted from excise duty. Income tax exemption on } \\
\text { net export earnings decreased from } 100 \% \text { to } 50 \% \text {. }\end{array}$ \\
\hline 5 & 1986 & Software Policy & $\begin{array}{l}\text { Government made this policy for promoting software exports. Computers } \\
\text { systems used to develop software products for export could be imported duty } \\
\text { free. However, the importer was expected to export software and earn } 250 \% \text { of } \\
\text { the imported computer cost within } 4 \text { years. Software developed in India could } \\
\text { be exported using satellite communication facilities and exporter communicates } \\
\text { with their off } \square \text { shore clients. Customs duty on imported computer system for } \\
\text { software export was reduced. }\end{array}$ \\
\hline 6 & 1988 & $\begin{array}{l}\text { Software } \\
\text { Technology Park } \\
\text { Scheme }\end{array}$ & $\begin{array}{l}\text { STP was established under the Department of Electronics \& Information } \\
\text { Technology. It was autonomous body to encourage and support small-medium } \\
\text { software exporters. The STP scheme is a } 100 \% \text { export oriented scheme for the } \\
\text { development and export of software products and services. This scheme also } \\
\text { provided single window clearance and permission of } 100 \% \text { foreign equity. } \\
\text { STP units are } 100 \% \text { duty free on import of hardware and software. Units were } \\
\text { exempted from payment of corporate income tax up to } 2010 \text {. They were also } \\
\text { provided infrastructure such as buildings, computers, high-speed satellite com- } \\
\text { munication links and an uninterrupted power supply. }\end{array}$ \\
\hline 7 & $\begin{array}{l}1992- \\
95\end{array}$ & $\begin{array}{l}\text { Import duties } \\
\text { on imported } \\
\text { software }\end{array}$ & $\begin{array}{l}\text { Government decreased } 20 \% \text { import duties on application software and } 65 \% \text { on } \\
\text { systems software in the year 1994. Decreased } 10 \% \text { on both in } 1995 \text {. }\end{array}$ \\
\hline 8 & $\begin{array}{c}1993- \\
99\end{array}$ & $\begin{array}{l}\text { Income-tax } \\
\text { exemptions }\end{array}$ & $\begin{array}{l}\text { The Software exports were exempted from income tax and this tax-free status } \\
\text { was confirmed every year till } 1995 \text { after which it became open-ended. }\end{array}$ \\
\hline 9 & 2000 & $\begin{array}{l}\text { Information } \\
\text { Technology Act } \\
2000\end{array}$ & $\begin{array}{l}\text { The Act provides legal status for electronic governance by giving recognition } \\
\text { to electronic records and digital signatures. It is the crucial law in India which } \\
\text { deals with e-commerce and cybercrime. It permitted the use of digital signature } \\
\text { on documents and also allowed to establish public key certifying authorities } \\
\text { and permitted to convert any legal documents into digital form. It also specified } \\
\text { legal punishment for 'Cybercrimes', for example hacking websites, databases or } \\
\text { whole system, and financial frauds. }\end{array}$ \\
\hline 10 & 2005 & $\begin{array}{l}\text { Special Eco- } \\
\text { nomic Zones } \\
\text { Act }\end{array}$ & $\begin{array}{l}\text { The creation of SEZs in the country for generation of foreign exchange and } \\
\text { attract FDI. } 100 \% \text { Income Tax exemption on export earnings from SEZs unit. } \\
\text { Exemption from 'central sales tax', 'service tax' and duty free import. SEZs Act } \\
\text { provided single window clearance and duty free import on hardware. }\end{array}$ \\
\hline 11 & 2015 & $\begin{array}{l}\text { Policy on Adop- } \\
\text { tion of Open } \\
\text { Source Software } \\
\text { for Government } \\
\text { of India }\end{array}$ & $\begin{array}{l}\text { Government has been promoting the use of open source technologies in the } \\
\text { e-Governance domain in order to increase economic and strategic benefits. } \\
\text { This policy will encourage the formal adoption and use of OSS in government } \\
\text { agencies. The source code of software will be available for the end-user to study } \\
\text { and modify. Source code of software will be free from any royalty. }\end{array}$ \\
\hline
\end{tabular}

Source: Own compiled on the basis of data given by Athreye, 2005 Rajaraman, 2010 and GOI, 2015. Note: GOI- Government of India. 


\section{Software Technology Parks in India (STPI)}

STPI were setup in the year 1990 under the Department of Electronics and Information Technology. It created facilities of infrastructure such as buildings, R\&D work stations, power supply, high speed internet and satellite links to the software companies registered in these parks. The Bangalore was first city where STPs were setup and it emerged as global IT Hub for software development (Rajaraman, 2010). STPI are located at 15 major cities in India such as Pune, Noida, Bangalore, Hyderabad, Thiruvananthapuram, Gandhinagar, Bhubaneshwar, Mohali, Jaipur, Mumbai, Mysore, Coimbatore, Manipal, Vizag, Guwahati and Chennai. The STP scheme is a $100 \%$ export oriented scheme for the development and export of software product and services. This scheme also provides single window clearance import certification, software valuation, permission of $100 \%$ foreign equity, marketing support and training facilities (Athreye, 2005).

Table 6: The Performance of STP Units from 2010 to 2016

\begin{tabular}{|c|c|c|c|}
\hline Year & Newly Registered STP & Operating Units & Exporting Units \\
\hline $2010-11$ & 294 & 6554 & 5565 \\
\hline $2011-12$ & 133 & 5235 & 4542 \\
\hline $2012-13$ & 109 & 4534 & 3755 \\
\hline $2013-14$ & 115 & 3676 & 3335 \\
\hline $2014-15$ & 106 & 3124 & 2832 \\
\hline $2015-16$ & 105 & 1119 & 2525 \\
\hline
\end{tabular}

Source: Own compilation based on annual report of STPI from 2011 to 2016

The preceding table 6 shows the commendable performance of STP units. During the year 2010, 294 new units were registered, 6554 units were operative and 5565 units were exporting. By the 2016, 105 new units were registered under the STP scheme, 1119 units were operative and 2525 units were exporting. There were total 53 STPI centres in working mode across the country and out of 53 centres, 46 centres are in Tier-II and Tier-III cities during the year 2014 (STPI, 2014).

Table 7: State Wise Performance in Software Exports Made by STPI Units from 2010 to 2016 (in Rs. Crore)

\begin{tabular}{|l|l|l|l|l|l|l|l|}
\hline $\begin{array}{l}\text { Sr. } \\
\text { No }\end{array}$ & $\begin{array}{l}\text { Name of } \\
\text { State }\end{array}$ & $2010-11$ & $2011-12$ & $2012-13$ & $2013-14$ & $2014-15$ & $2015-16$ \\
\hline
\end{tabular}

Innovation and Development in Information 
Solanki, D. K.

Sinha, K.

\begin{tabular}{|c|c|c|c|c|c|c|c|}
\hline 1 & $\begin{array}{l}\text { Andhra } \\
\text { Pradesh }\end{array}$ & 28674.57 & 28948 & 34492 & 36752.95 & 379.54 & 477.93 \\
\hline 2 & Assam & 10 & 6.58 & 0.92 & 0.88 & 1.35 & 0.18 \\
\hline 3 & Bihar & NA & 17 & 8.14 & 9.7 & 10.63 & 7.25 \\
\hline 4 & Chandigarh & 413.9 & 492.76 & 405.1 & 558.49 & 519.89 & 700.79 \\
\hline 5 & Chhattisgarh & 4.58 & 8.58 & 12.29 & 17.48 & 18.63 & 23.29 \\
\hline 6 & Delhi & 1541.2 & 3604.39 & 1461.51 & 1173.02 & 2217.85 & $1,442.30$ \\
\hline 7 & Goa & NA & NA & NA & 77 & 94.59 & 117.17 \\
\hline 8 & Gujarat & 1250.99 & 1116.05 & 982.4 & 1442.48 & 1917.76 & $2,224.55$ \\
\hline 9 & Haryana & 13650.75 & 13506.81 & 15363.69 & 18327.4 & 17857.69 & $19,265.44$ \\
\hline 10 & $\begin{array}{l}\text { Himachal } \\
\text { Pradesh }\end{array}$ & 0.9 & 0.87 & 6.28 & 4.67 & 8.35 & 5.16 \\
\hline 11 & $\begin{array}{l}\text { Jammu \& } \\
\text { Srinagar }\end{array}$ & 0.8 & 0.76 & 1.41 & 2.18 & 2.45 & 3.35 \\
\hline 12 & Jharkhand & 2.1 & 6.26 & 7.04 & 8.66 & 7.00 & 49.16 \\
\hline 13 & Karnataka & 70240.93 & 82110 & 95048.25 & 103720.16 & 109797.67 & $1,25,418.53$ \\
\hline 14 & Kerala & 2071.67 & 1982.64 & 2240.7 & 2665.12 & 2867.77 & $3,008.91$ \\
\hline 15 & $\begin{array}{l}\text { Madhya } \\
\text { Pradesh }\end{array}$ & 246.89 & 237.23 & 244.54 & 301.99 & 343.38 & 355.00 \\
\hline 16 & Maharashtra & 49873.78 & 46262.9 & 49796.3 & 55419.79 & 61314.29 & $64,063.59$ \\
\hline 17 & Meghalaya & 1.64 & 2.24 & 2.59 & 2.84 & 4.21 & 6.31 \\
\hline 18 & Orissa & 1253.29 & 1410 & 1702.43 & 1919.09 & 1940.00 & $2,179.72$ \\
\hline 19 & Pondicherry & 110.25 & 118.2 & 117.2 & 120 & 153.26 & 182.55 \\
\hline 20 & Punjab & 438.43 & 351.04 & 505.21 & 340.38 & 336.34 & 324.83 \\
\hline 21 & Rajasthan & 491.65 & 493.63 & 637.76 & 664.06 & 712.27 & 803.97 \\
\hline 22 & Tamil Nadu & 28289.75 & 29081.8 & 29182.8 & 29880.2 & 33275.73 & $33,905.30$ \\
\hline 23 & $\begin{array}{l}\text { Uttar } \\
\text { Pradesh }\end{array}$ & 10944.75 & 10989.39 & 13194.68 & 13352.66 & 13740.34 & $16,450.68$ \\
\hline 24 & Uttarakhand & 86.32 & 44.92 & 54.54 & 69.27 & 74.67 & 82.57 \\
\hline 25 & West Bengal & 5665 & 5920 & 6030 & 6482.22 & 7015.00 & $6,990.00$ \\
\hline $\begin{array}{l}\text { To- } \\
\text { tal }\end{array}$ & & 215264.14 & 226712.05 & 251497.78 & 273312.69 & 254610.66 & 278088.53 \\
\hline
\end{tabular}

Source: Own compilation based on annual report of STPI from 2011 to 2016

Journal of Technology Management for Growing Economies, Volume 8, Number 2, October 2017 
The overall performance of registered STP units increased every year and it became major player in employment generation besides earning foreign currency through export. The above table 7 shows state wise export contribution of STPI registered units across India. There are 25 states which are playing major role in software export. State wise STPI's overall exports of software products were increased from 215264.14 crore in $2009-10$ to 278088.53 in 2015-16. The overall exports done by STPI registered IT/ITeS units increased from 2,93,797Crore in 2014-15 to 3,19,569Crore in 2015-16 (STPI, 2016). The STPI's remarkable contribution to software-exporting sector is through provision of high speed data communication services, power supply and infrastructure facilities.

\section{Role of Industrial Association (NASSCOM)}

NASSCOM, association for Indian software industry was established in the year 1988. Software and services companies were formed by NASSCOM and Dewang Mehta was president during the year 1991. Association played significant role in directing government to make policies, gain access to capital markets, make rules for transaction of foreign revenue, increasing telecommunication facilities for the software development and services industry. The NASSCOM established SIG to resolve Y2K bug problem or millennium problem in the year 1996. The National Institute for Smart Governance was established at Hyderabad in the year 2002 through a joint programme of NASSCOM and Government of Andhra Pradesh. The beginning of NASSCOM with 38 software firms registered as members in 1988 increased up to 1000 members in the year 2005 (Rajaraman, 2010). At the end of year 2016, more than 2200 IT/ITeS firms were registered to NASSCOM.

NASSCOM made significant contribution to create India's brand in domestic and international software development and services market. With the creation of major IT-Expo events and participating in international trade fair India became key player in global software market. Every year NASSCOM publishes an annual report which gives detailed information about member firms. Annual report contains all the information such as sales (import and export), employment generation, certification and information about registered company. The NASSCOM has become a reliable source of information related to software firms in India (Bhatnagar, 2006).

\section{CONCLUSION}

The Indian government is promoting 'Digital India' and 'Make In India' programmes as an umbrella programmes to prepare India for knowledge based transformation into a digitally empowered society along with knowledge
Innovation and Development in Information 
Solanki, D. K. Sinha, K. based economy. The Government has been encouraging the growth of the sector by funding projects under various programs of Deity, DST, MHRD. The other stakeholders such as universities, technical research institutes and private - public firms such as TCS, INFOSYS, C-DAC, BISAG are also key important players in this area. The government had made policies to encourage the domestic software export and development of local firms during 1972 to till now. There are number of policy changes regarding software export duties and tax. The Department of Electronics and Information Technology has taken many initiatives for promotion and adoption of Free \& Open Source Software for increasing foreign exchanges, developing indigenous products and achieving vendor's independence. Other side, India largely has Microsoft dependent environment and other foreign vendor's software products in terms of operating system and its usage in personal computers, tablets, smart phones. The software users are still dependent on Microsoft and other foreign vendor's software products for our personal computer's basic software such as operating system, office tools and also on other IT-business related software. Therefore, it is necessary to develop indigenous software products and services and create an encouraging environment for the growth of BOSS and other Indian products. There are also other necessary step must be taken for small domestic software market, slow and limited communication service, slow and expensive internet service, insufficient electricity, slow government operation and transportation services are also hurdles for IT- Software firms in India. The developing country like India is still working on creation of indigenous software products for desktop, laptops, smart phones and tablets. In future latest technologies will be provided by India to national and International software market.

\section{REFERENCES}

AICTE.(2015). Statistics.All India Council for Technical Education, New Delhi. Retrieved on Dec 2015 from http://www.aicte-india.org/sallstatewisehtm.php

AICTE.(2016). Aicte approved institutes for the academic year: 2015-2016. All India Council for Technical Education, New Delhi. Retrieved on Dec 2016 from http://www.aicte-india. org/dashboard/pages/dashboardaicte.php

Athreye, S.S. (2005).The Indiansoftware industry and its evolving service capability. Industrial and corporate change. Oxford University Press, 1-26. https://dx.doi.org/10.1093/icc/dth056

Bhattacharjee, S., \&Chakrabarti, D. (2015). Investigating India's competitive edge in the IT-ITeS sector. IIMB Management Review, 27, 19-34. https://dx.doi.org/10.1016/j. iimb.2015.01.003

Bhatnagar, S. (2006). Indian software industry. Technology, Adaption and exports: How some developing countries got it right.In V. Chandra (Eds.), World Bank, 95-124.

Buyya,R.,Vecchiola,V., \& Selvi,S,T .(2013). Mastering cloud computing foundations and applications programming. Elsevier

Chadha, V., Sachdeva, H., \&Choudhary, P. (2015). Incongruity between the generations: Requirement and employment of technical workforce in India's ICT sector. Man \&Devalopment, 37(3).

Journal of Technology Management for Growing Economies, Volume 8, Number 2, October 2017 
Deity.gov.(2015). Major foss initiatives.Department of Electronics \& Information Technology, New Delhi.Retrieved on Nov 2015 from http://deity.gov.in/ content/major-foss-initiatives Deity.(2015). Performance contribution towards exports-it-ites industry.Department of Electronics \& Information Technology, New Delhi. Retrieved on Nov, 2015 from http://deity. gov.in/content/performance-contribution-towards-exports-it-ites-industry

Deity. (2017). Performance \& Contribution towards Exports by IT-ITES Industry. Department of Electronics \& Information Technology, New Delhi. Retrieved on June, 2017 from http://meity.gov.in/content/performance-contribution-towards-exports-it-ites-industry

Engelhardt, S.V. (2008). The Economic Properties of Software.Jena Economic Research Papers, 45, 1-24. http://dx.doi.org/10.2139/ssrn.1430885.

Fagerberg, J. (2005). Innovation: A guide to the literature. In J. Fagerberg, D.C. Mowery, \& R.R. Nelson (Eds.), The Oxford handbook of innovation (pp.1-27). New York: Oxford University Press. http://dx.doi.org/10.1093/oxfordhb/9780199286805.003.0001.

Freeman, C. (1987).Technology Policy and Economical Performance: Lessons from Japan. Printer Publishers, London.

GOI.(2015). Framework For Adoption of Open Source Software In e-Governance Systems. Department of Electronics and Information Technology. Government of India. Retrieved on Dec, 2016 from http://egovstandards.gov.in/sites/default/files/Framework $\% 20$ for $\% 20$ Adoption $\% 20$ of $\% 20$ Open $\% 20$ Source $\% 20$ Software $\% 20$ in $\% 20$-Governance $\% 20$ Systems. pdf.

Grohn, A. (1999). NetzwerkeffekteundWettbewerbspolitik.Eineökonomische Analyse des Software marktes, Mohr Siebeck, Tübingen.

Kumar, N. (2001). National innovation systems and the Indian software industry development.World Industrial Development Report 2001 UNIDO. Retrieved on April 2016 from http://www.unido.org/fileadmin/import/userfiles/hartmany /idr-kumar-paper2.pdf. https:// dx.doi.org/10.1017/CBO9781139794640.006.

Kulkarni, S. (2015). A Brief report on IT\&ITES industry in India. Corporate catalyst (India) Pvt. Ltd. Retrieved on Feb 2016 from http://www.cci.in/pdfs/surveys-reports/IT-andITeS-Industry-in-India.pdf

Kshetri,N., Fredriksson,T., \&Rojas,D,C. (2017). The big data and Cloud computing: Lessons from key industries and economies in the global south. New York: Routledge publication.

Lundvall, B. A. (1992). National system of innovation: Towards a theory of innovation and interactive learning. London: Pinter

Mohammed, A. (2010). Jordansoftware industry: Investigating the role of human capital. International Journal of Business and Management, 6(5). http://dx.doi.org/10.5539/ijbm. v6n5p217.

MHRD.(2015). Document-Reports.Ministry of Human Resource Development.Government of India, New Delhi. Retrieved on Feb 2015 from http://mhrd.gov.in/sites/upload_files/mhrd/ files/document-reports/Part1.pdf

MHRD.(2016). Document-Reports.Ministry of Human Resource Development.Government of India, New Delhi. Retrieved on June 2017 from http://mhrd.gov.in/sites/upload_files/ $\mathrm{mhrd} /$ files/document-reports/AR 2015-16\%20 ENGLISH.pdf

Nicholson, B., \&Sahay, S. (2008). Human resource development policy in the context of software exports: Case evidence from costa cica progress. Development Studies, 8, 163-176.

NASSCOM. (2014). The IT-BPM sector in India: Strategic review. National Association of Software and Services Companies, New Delhi.

Nelson, R. (1993). National system of innovation: A comparative study of oxford. Oxford university press.

Parthsarathi, B. (2004). Globalizing information technology: The domestic policy context for India's software production and exports. Iterations: An Interdisciplinary Journal of Software History, 3, 1-38.

Rajaraman, V. (2010).History of computing in India (1955-2010). Retrieved on Oct, 2015
Innovation and

Development in Information 
Solanki, D. K. Sinha, K. from http:/www.cbi.umn.edu/hostedpublications/pdf/Rajaraman HistComputingIndia.pdf STPI. (2014). STPI Annual Report 2011-14. Software Technology Park of India, New Delhi. Retrieved on 2015 from https://www.stpi.in/11010120001301340140192

STPI. (2016). STPI Annual Report 2011-16. Software Technology Park of India, New Delhi. Retrieved on 2017 from https://www.stpi.in/11042

Sharma, D.C. (2014). Indian IT outsourcing: Future threats and challenges. Future, 56, 73-80. https://dx.doi.org/10.1016/j.futures.2013.10.011.

Vijayasri, G. (2013). The role of information technology (it) industry in India. International Monthly Refereed Journal of Research In Management \& Technology, 2, 55-64. 